some sources from which data can be obtained for these centuries, and has outlined the use to which they may be put in the county of Sussex. The distribution of various types of building-stone, when a stone was used outside its area of occurrence in the fabric of a church, throws light on means of transport, especially the navigability of rivers, since waterways were the only satisfactory means of moving heavy materials. Evidence of this source can be strengthened by sheriffs' administrative accounts. These do not give the precise route but the distance and the cost of transport. The sheriffs' accounts also give much evidence concerning the distribution of crops, timber, and wool production. Lastly, much valuable information can be obtained from taxation accounts, particularly the lay subsidy of 1327. This gives a guide to the location of the areas of greatest prosperity. Mr. Pelham has illustrated his paper with maps of various aspects of the fourteenth century geography of Sussex.

\section{Ice in Arctic Seas}

THE Danish Meteorological Institute has published its report on the ice in arctic seas in 1930 (Isforholdene $i$ de Arktiske Have). There appears to have been a repetition of the unusual conditions marked by the lack of ice in many seas in 1930. In Spitsbergen the fjord ice was late in forming and relatively thin, and so early as April the western part of the north coast had open water, and by June there was access to the north-east. During July and August the waters of the archipelago were almost free from ice. In the Barents Sea the edge of the ice was unusually far north throughout the summer, and in August a great deal of Franz Josef Land was accessible in open water, which is not usual. The Kara Sea had scattered ice in July but was almost entirely clear in August. So late as November there was little ice in the White Sea. In the east coast of Greenland conditions were less abnormal, but from August until November there was little or no ice off Angmagssalik. The coasts of Iceland were free from ice throughout the year, and south-west Greenland had less ice than usual. Hudson Strait was clear of ice about a month earlier than usual and, except for icebergs, was still free in October. From Siberian waters there were few reports. On the north coast of Alaska the ice lay closely packed throughout the summer. The report is illustrated with the usual charts for each of the spring and summer months.

\section{Abstracts of Meteorological Literature}

The Meteorological Magazine for March 1932 contains particulars of a collection of abstracts of meteorological literature which has been undertaken by the Meteorological Office, Air Ministry. The abstracts are being gathered from various sources, including authors' own summaries, translated into English where necessary, and a number of meteorologists have volunteered their assistance in summarising papers for which no abstracts are otherwise available. The collection already numbers about a thousand, covering a period of nearly ten years, and it is hoped to include every important paper published in future. The abstracts are being classified according to subject, the classification adopted being that of the International Catalogue of Scientific Literature, which is also employed in the Royal Meteorological Society's Bibliography; the new collection of abstracts will thus form a very useful complement to the latter. The abstracts will not be published, but will be kept in the Meteorological Office Library for reference.

\section{Bibliography of Seismology}

THE study of earthquakes and of the transmission of earthquake waves through the earth has lately made such rapid advances that any attempt to enumerate the memoirs published is welcome. We have received from the Dominion Observatory at Ottawa, which is now solely responsible for its publication, copies of recent issues of the Bibliography of Seismology, edited by Mr. E. A. Hodgson. The number for July-Sept. 1931 contains the titles, with occasional brief abstracts, of a hundred papers. Most countries in which earthquakes are studied are represented, though somewhat unequally, more than one-half of the papers being published in the United States and Great Britain and only two in Italy.

\section{British School of Archæology in Iraq}

IT is announced that the subscribers to the fund for establishing a British School of Archæology in Iraq in memory of the late Miss Gertrude Bell have appointed a council on which the Universities of Oxford, Cambridge, Edinburgh, Durham, and London are represented. In addition, there are representatives of the British Museum, the British Academy, the Royal Geographical Society, the Royal Asiatic Society, the Society of Antiquaries, and other learned societies. The following have been appointed as officers: Sir Percy Cox (president), Sir Edgar Bonham Carter (chairman of the executive committee), Mr. E. H. Keeling (hon. secretary), and BrigadierGeneral Sir Osborne Mance (hon. treasurer). The offices of the School for the present will be at 20 Wilton Street, London, S.W.

\section{Scenery Preservation in New Zealand}

THE preservation of natural scenery by the institu. tion of reserves is an active policy of the New Zealand Government. The report on scenery preservation of the year ending March 31, 1931, records additional re. serves during the year of 131,415 acres, making a total of well over half a million acres. Notable additions include Lake Okareka and surroundings, and some two hundred square miles embracing the Fox Glacier, and the Copland and Twain Rivers, and many prominent mountain peaks. Some of the smaller reserves have been set aside for historical and anthropological reasons, but most are scheduled in order to preserve scenery and natural vegetation.

\section{Announcements}

THE Kelvin Medal of the Institute of Civil Engineers for 1932 has been awarded to the Marchese Guglielmo Marconi, and the presentation will be made by Lord Rutherford at the Institute on Tuesday next, May 3, at 5 P.M.

A VARLEX centenary commemoration meeting will be held at the Institution of Electrical Engineers on 
May 5. A short discourse on the lives and work of Cromwell Fleetwood Varley (April 6, 1828) and Samuel Alfred Varley (March 22, 1832) will be delivered by Lieut.-Col. A. G. Lee. The annual general meeting of the Institution will follow this meeting.

Three public lectures arranged by the National Institute of Industrial Psychology (under the Heath Clark Bequest), on "Psychological and Social Factors in Business Rationalisation ", will be delivered by Dr. Charles S. Myers, principal of the National Institute of Industrial Psychology, May 4, 11, and 18, at 5.30 P.M. The lectures will be given at the London School of Economics and Political Science, Houghton Street, Aldwych, W.C.2.

THE writer of the obituary notice of the late Sir Horace Plunkett which appeared in NATURE for April 16 has been reminded that Sir Robert Blair was Assistant Secretary for Technical Instruction in the new Irish Department from 1900 until 1904, before he became Education Officer of the London County Council. The two 'aliens' whom Sir Horace introduced were thus both Scots.

A Preliminary programme has been issued of the centenary meeting of the British Medical Association, to be held in London on July 21-30 under the presidency of Lord Dawson of Penn. The meetings will be held at the British Medical Association House, Tavistock Square, W.C.1. Lord Dawson will deliver his presidential address on July 26 at the Queen's Hall. The popular lecture to the Association will be delivered on July 29 by Prof. Julian S. Huxley. An exhibition of surgical appliances, drugs, foods, books, etc., will be open on July 26-29 at the University of London, Imperial Institute Road, S.W.7. On July 24 a pilgrimage will be made to Worcester to unveil two memorials to Sir Charles Hastings, who founded the Association there in 1832 .

THE programme of experiments to be carried out during the coming season at Jealott's Hill, the Agricultural Research Station of Imperial Chemical Industries, Ltd., at Bracknell, near Maidenhead, Berks, includes experiments on fertilisers for grain, root, and green crops, and also on the intensive management of grassland. The demonstrational small-holding has entered its second complete season, and the results of the first year's working are available. An open invitation is extended to all interested in agriculture to inspect the Station. Visitors are the guests of the Station at lunch or tea, but it is desirable that two or three days' notice should be given of an intended visit.

THE advanced courses in anthropology, sociology, and comparative philology in the University of London announced for delivery in May promise to be of exceptional interest. On May 2, 4, and 6, Prof. G. Morgenstierne of the University of Gothenburg will lecture on "The Káfirs of the Hindu Kush". The lectures will be delivered at 5.30 P.M. at the School of Oriental Studies, Finsbury Circus, E.C., and will deal with the ethnology and culture of the people, as well as with their linguistics. On May 5 and 12, at 5 P.M., Dr. R. R. Marett, Rector of Exeter College, Oxford, will lecture at the London School of Economics on "Covenant in Primitive Economics, Law, and Religion ". Prof. A. M. Tallgren, professor of archæology of Finland and the Northern Countries in the University of Helsingfors, will lecture at University College on May 23 and 25 on "Central Asiatic and Siberian Rock Pictures". The lectures will begin at 5.30. Admission to all these lectures is free and without ticket.

A CATALOGUE of second-hand books on natural history has been issued by James Thin, 54-56 South Bridge, Edinburgh. The 2497 items in the list range over a wide field in zoology, botany, and agriculture and husbandry.

A NEw book by Max Planck, entitled "Where is Science Going ?", with introduction and epilogue by Einstein, is promised by Messrs. Allen and Unwin for the autumn. These publishers also announce "Science: A Symposium", a collection of essays by Bertrand Russell, Prof. Julian Huxley, Prof. J. B. S. Haldane, Hilaire Belloc, Sir Oliver Lodge, Sir Thomas Holland, John Baker, Hugh L'Anson Fausset, and Prof. H. Levy.

A NEW publication dealing with general and comparative physiology has been undertaken by the Wistar Institute of Anatomy and Biology, Philadelphia. This Journal of Cellular and Comparative Physiology, which will be published in alternate months, under a responsible board of editors, commenced publication on Feb. 20. The volume will contain about 500 pages and may be closed with any issue. The price will be 5.50 dollars outside the United States.

Applications are invited for the following appointments, on or before the dates mentioned:-An assistant lecturer in agricultural economics in the University of Leeds-The Registrar, University, Leeds (May 2). An assistant veterinary inspector under the Surrey County Council-The Chief Veterinary Officer, County Hall, Kingston-upon-Thames (May 10). A superintendent of Epping Forest-The Town Clerk, Guildhall, E.C.2 (May 11). A woman lecturer in geography at St. Gabriel's College, Camberwell - The Principal, St. Gabriel's College, Cormont Road, Camberwell, S.E. (May 14). A lecturer in geography at Armstrong College--The Registrar, Armstrong College, Newcastle-upon-Tyne (May 14). Two assistant lecturers in the School of Economics and Commerce, Dundee, in, respectively, industrial administration and commerce--The Principal, School of Economics and Commerce, Dundee (May 23). A director of the British Non-Ferrous Metals Research Association-The Chairman of the Association, 168 Regent Street, W.1.

Erratum.-In the article "Flame Movements in Gaseous Explosions ", in Nature for April 16, p. 565, line 5, for "Campbell and Woodward (1926)" read "Campbell and Woodhead (1926)".

No. 3261, VoL. 129] 